phenomenon that more living, reproducing matter has been generated from a body than it ever contained.

Lay readers will appreciate the effort that kept Landecker's scholarly and original book short and accessible. There is inevitably more for specialist historians to do. The epilogue, which interprets the cloning of adult mammals as dependent on freezing and synchronizing cells, whets the appetite for a fuller discussion of cell-cycle work. It also raises the larger question of how the histories of somatic cells and of gametes have intertwined. Answering it, and more generally gaining a sense of the place and status of cell culture in biology, would have taken the book beyond journal and newspaper articles to the realm of textbooks and other synthetic works. But these are suggestions for research that happily can now build on Landecker's stimulating reconstruction of the cultures that gave us cultured cells. Nick Hopwood is in the Department of History and Philosophy of Science, University of Cambridge, Cambridge CB2 3RH, UK, and is coeditor of Models: The Third Dimension of Science (Stanford University Press, 2004).

\title{
A scientific symphony
}

\section{Harmonious Triads: Physicists, Musicians, and Instrument Makers in Nineteenth-Century Germany by Myles W. Jackson \\ MIT Press: 2006.368 pp. \$40, £25.95}

\section{Peter Pesic}

Why are so many scientists musical and so many musicians scientific? This relationship goes back to antiquity, but remains largely unexplored. In his book Harmonious Triads, Myles Jackson, a historian of science and an accomplished cellist, examines nineteenthcentury Germany, where science and music interacted with particular intensity.

He begins with the physicist Ernst Chladni, who in the 1780 s sprinkled sand on vibrating plates to produce fascinating images of wave motion. Jackson relates this exemplary demonstration to Chladni's novel musical instruments (have you heard of his euphone or clavicylinder?). These instruments were informed by the physics of vibrating bodies, which had both musical and commercial possibilities. But musical observations also informed science: for example, Chladni's production of longitudinal vibrations led to the intensive study of their properties, which was crucial for the development of wave theory.

Chladni considered his demonstrations not entertainment but Bildung, the quest for education and personal edification so important in German thought. Likewise, Jackson depicts German scientists and physicians using choral singing as a central unifying activity at their meetings, celebrating their camaraderie while augmenting their musicality and fuelling their patriotism. Alexander von Humboldt once invited the composer Felix Mendelssohn to write a festive cantata, which you can hear on the book's website (http://mitpress.mit.edu). Why do our scientific meetings no longer include 'singing savants'?

Music celebrated science, but the conflict between organic and mechanical views lay behind Goethe's distrust of newtonian science, as well as the musical automata animating E. T. A. Hoffmann's unforgettable stories.
Nothing less than the soul was at stake: Jackson emphasizes that "audiences did not want to be entertained; they now wished to be moved". Accordingly, builders sought to make pipe organs more expressive by enabling them to swell in volume, despite the difficulty of making the sound louder without its pitch rising. This problem led physicist Wilhelm Weber and others to important research on the speed of sound and the specific heat of various gases. By then, however, the taste for expressively swelling reed organs had (mercifully) diminished.

In the process, both musical and physical developments had led to an ever-increasing emphasis on precision and standardization. Jackson's description of the struggle over an international pitch for concerts discloses a whole comédie humaine. Who would tune the concert of Europe? Each nation vied for pre-eminence by insisting on its own pitch
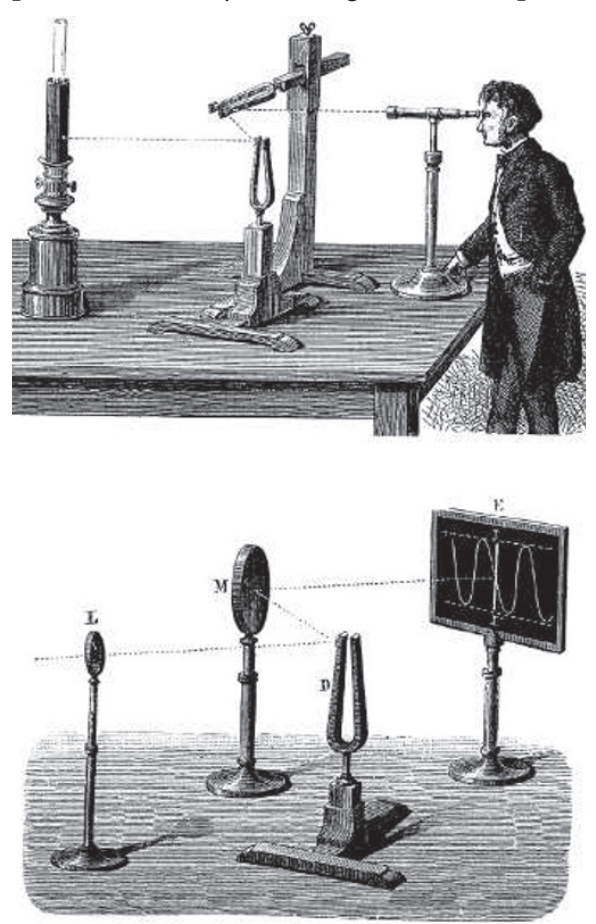

Sound idea: Jules Lissajous used light and mirrors to increase the precision of tuning forks. standard, from Paris (where A above middle C was tuned to $435 \mathrm{~Hz}$ ) to London (A455); by comparison, Mozart's own tuning fork sounded A422. An international conference convened in Vienna in 1885 chose the Parisian pitch, using arguments guided more by diplomatic finesse than musical purity. As one contemporary musician put it, using a higher pitch standard destroyed the "effect and character of ancient music - of the masterpieces of Mozart, Gluck, and Beethoven", who expected a lower pitch standard and did not wish their singers to strain a semitone past the pitches they had intended. Recent 'authentic' performances at the older, lower pitch standard have tried to reverse this trend.

Small comfort, then, that these new tuning forks were regulated by the research of physicists Jules Lissajous and Josef Stefan. Nor was the imposition of equal temperament (artificially equalizing the size of all semitones) an unmitigated boon, despite its simplicity and advantages in scientific eyes. Jackson's account of "the fetish of precision" in temperament describes how Johann Heinrich Scheibler and others produced increasingly accurate forks that enabled the tuning of keyboard instruments with unprecedented precision. This erased the earlier unequal temperaments used by J. S. Bach and his successors, in which each key had an individual character.

No less controversial was the development of the metronome. At first Antonio Salieri hailed the machine as "the true interpreter of the ideas and feelings of every composer". But soon its mechanical rigidity seemed only "a dumb thing; one must feel the tempi," as Beethoven put it.

At least the metronome could drill novices into developing a steady beat. Jackson concludes with the parallel development of other pedagogic torture devices that held a piano student's hand in the correct position using guide rails, such as Johann Bernhard Logier's chiroplast. These increasingly popular mechanical aids accompanied the spread of piano-playing as an indispensible bourgeois accomplishment, along with an idea of virtuosity that encompassed sheer speed, rather than depth of expression. Jackson concludes with fin de siècle controversies over how a pianist touching a key can create ineffable results beyond the scope of a mere mechanism.

Jackson brings forward both harmony and tension between science and music, for "the freedom of the individual to cultivate his or her own character and taste, the role of the State in defining those attributes, and the relationship between the organic and the mechanical were at stake." MIT Press should be commended for producing this beautiful volume. Jackson's outstanding book is an essential source for everyone interested in the relationship between music, technology and science.

Peter Pesic is tutor and musician-in-residence at St John's College, Santa Fe, New Mexico 87505, USA 